\title{
ALTERATION OF URBAN MICROCLIMATE IN BANDUNG, INDONESIA BASED ON URBAN MORPHOLOGY
}

\author{
Beta PARAMITA ${ }^{1}$, Wayan SUPARTA ${ }^{2}$
}

DOI: 10.21163/GT_2019. 141.35

\begin{abstract}
:
Urban villages (kampongs) in developing countries have become urban morphological phenomena and their organic growth does not have adequate land use planning. This paper aims to discuss aspects of microclimate in urban environments. We explored the morphological aspects of urban villages which have implications for the formation of microclimates and have an effect on changes in urban climate. Nine village locations in Bandung were taken as research samples, namely: Sukajadi, Tamansari, Sukapada, Cigondewah Kidul, Cigondewah Rahayu, Cicendo, Babakan Ciamis, and Cihaurgeulis. The results of detailed and specific discussions in the aspects of mass and shape of buildings, the distance between buildings, the height of buildings, and the availability of green open spaces found a significant influence on the physical aspects of morphology in microclimates, mainly through weather parameters such as average radiation temperature, air temperature, relative humidity, and wind speed.
\end{abstract}

Key-words: Urban Climate Alteration, Bandung Urban Village, Microclimate

\section{INTRODUCTION}

The complexity of urban tissue which contains spatial such as land-use and its morphology (building and open space) connected to the operational system like transportation, water system within them are giving the significant impact to the urban climate (Gavris, 2012; Nistor, 2018). The cities with high density and morphological characteristics such as high dwelling units and population but low floor area ratios led to an overcrowded area. The urban structure in three dimensional, such as building height, orientation, street canyon plays contribution to Albedo and aerodynamic roughness (Oliveira 2016; Matzarakis \& Mayer, 2008). Each of them able to control of radiative exchange and urban ventilation (Matzarakis et al., 2007). Thus, the surface properties and anthropogenic emission are both urban features that able to modify the atmosphere. The characteristic of urban life gives the fluctuate output of anthropogenic emission; depend on the daily human activity. The alteration of urban climate then becomes unavoidable to depend on the urban morphology. The rapid change of land-use caused by urbanization becomes the focus of this study.

Southeast Asian cities are the world's fastest growing regions of population and urban growth. It is $54.9 \%$ that population live in the urban area, whereas the $57.6 \%$ of them are in the Asia continent (Demographia, 2017). The implications for urbanization, not only include social aspects, but also more to the physical aspects of the city, such as land use, energy, water and other resources. The burden of ecological footprint are often 200 times

\footnotetext{
${ }^{1}$ Universitas Pendidikan Indonesia, Architecture Program Study, Bandung, Indonesia, betaparamita@upi.edu;

2 Pembangunan Jaya University, Department of Informatics, wayan.suparta@upj.ac.id;
} 
greater than the urban area itself (Malakoff at al., 2016). It is unavoidable then, the population density, the change of urban land-use contributes its vulnerability to climate change (Gunawan et al., 2015; Yusuf \& Francisco, 2009; Manik \& Syaukat, 2015; Kalnay $\&$ Cai, 2003). The concept of land-sharing to reduce traffic volume and to provide green open space, as applied in Tokyo and Singapore, somehow was not just happen in Asian metropolitan cities in general, Bandung is no exception (Paramita, 2016). The increase of average air temperature, urban heat island phenomenon, hydrometeorology hazards become the most obvious vulnerability in Bandung City (Paramita \& Fukuda, 2014; Tursilowati 2013; BNPB, 2014). The previous study which correlated to urban morphology in Bandung shows that geographical location, building orientation, height and street canyon gives the different impact of the invention of microclimate (Paramita \& Fukuda, 2013, 2014). Specific discussion about the decline of green open space within urban area leads the increase of surface temperature in Bandung (Narulita et al., 2016; Ramdani \& Setiani, 2014). In the micro level building configuration gives the direct impact to microclimate which then leads the perception of outdoor thermal comfort. Meanwhile in the macro level, urban morphology gives the contribution to the alteration of urban climate.

\section{URBAN MORPHOLOGY AND URBAN BOUNDARY LAYER}

The effect of building geometry on surface temperature caused by radiation will have an impact on energy flux and airflow. The significant roughness of different land use, such as settlement, green open space as well as building types (high rise/low rise including its density) leads the horizontal and vertical flows between the surface and the atmosphere which known as the urban boundary layer (Collier, 2006; Harmon et al., 2004).

Characteristics of an urban village are population based on the region, insufficient infrastructure, and poor buildings physical condition (Heryati, 2008). By these characteristics, it could be said that the houses are not well built; both architecturally and aesthetically. The distance between houses is too close. So, the air circulation often becomes a problem related to the health of residents. Besides the air circulation, houses that are narrow in size and poor ventilation also become a problem for the residents' health. In Indonesia, there are still 38,431 hectares of slum areas in 4,108 areas spread throughout the city/district. Whereas in the city of Bandung, there were 121 villages / kelurahan which were labeled as slums.

In addition, the physical condition of the house also affect the city patterns. Houses which are arranged together create density. So, that formed an irregular pattern and chaotic city. Green open space which part of healthy settlements is no longer considered. Without green open space, the microclimate in the city village could be affected. Not available green open space as a source of oxygen causes the air exchange less good and less perfect. If the houses are built by poor material which cannot absorb the heat well, it could change in temperature or temperature increase and cause urban heat island. Urban heat island is a phenomenon that usually occurs in large cities where temperatures at night are hotter than the temperature in the morning due to the reflection of heat by building materials (Nuruzzaman, 2015).

Local diurnal temperatures in the West Bandung and North Bandung regions reach a maximum in the afternoon (at 4:00 pm) which are higher than the morning temperatures. The difference between the afternoon and morning temperatures reached $6-11^{\circ} \mathrm{C}$. This indicates the phenomenon of urban heat island has occurred in both regions. Broadly speaking, the increase in the average temperature of the city of Bandung also experienced 
an increased trend by $0.8^{\circ} \mathrm{C}$ over the past 20 years (Paramita \& Fukuda, 2014). Based on these, it is needed to examine the influence of buildings on microclimate in several urban villages. Changes in temperature have an influence on human health, both physically and psychologically.

\section{METHODS: STUDY AREA AND DATA}

Bandung is a provincial capital city of West Java with the densest area in any province of Indonesia. The highest density of Bandung is in Bojongloa Kaler District with 47,298 people $/ \mathrm{km}^{2}$ and the lowest density is in Gedebage District with 6,098 people $/ \mathrm{km} 2$, and the average density of Bandung is 14,831 people $/ \mathrm{km}^{2}$ (BPS Bandung, 2016). This study refers to the Bandung City RKP-KP database for urban villages with building density and physical environmental quality as the determination of research subjects. The city of Bandung has a hot and humid climate with high precipitation that is an average of $223 \mathrm{~mm}$ a year. This study discusses the database of the Bandung City for urban villages with building competencies and physical quality of the environment as a limitation of research subjects. The next step is to determine 9 areas that have high levels of slums. Each research location (sub-district) will determine six measurement spots, and meteorological data will be measured from 6:00 to 18:00 local time in 10 minutes intervals of each spot.

The aspect of physical area assessment is carried out by field measurements and through satellite map sequencing. Meteorological aspects are carried out by field measurements with two methods: gathering fixed data from ground-based weather stations from July to December (6 months), and the second method is via mobile data that measures the movement of six spots in one city village and is repeated from three to seven times. As in Table 1, the mobile experiment was held from April 2018 in Cigondewah Rahayu and ended in June 2018 at Sukapada. The final result of this step is to analyze the pattern on the urban climate alteration for each region.

Table 1. The location of measurement of microclimate in Bandung, West Java, Indonesia.

\begin{tabular}{|c|l|c|c|}
\hline No. & Sub-district name & Date of experiment & Number of measurements \\
\hline 1 & Cigondewah Rahayu & 18 April 2018 & 5 \\
\hline 2 & Sukajadi & 21 April 2018 & 3 \\
\hline 3 & Cigondewah Kidul & 25 April 2018 & 5 \\
\hline 4 & Nyengseret & 1 May 2018 & 4 \\
\hline 5 & Tamansari & 6 May 2018 & 5 \\
\hline 6 & Cihaur Geulis & 12 May 2018 & 5 \\
\hline 7 & Cicendo & 18 May 2018 & 4 \\
\hline 8 & Babakan Ciamis & 1 June 2018 & 5 \\
\hline 9 & Sukapada & 2 June 2018 & 7 \\
\hline
\end{tabular}

\section{RESULS AND DISCUSSION}

\subsection{Results}

Referring to Table 1, the field measurement results at the Cigondewah Rahayu with five rounds measurement fields showed the air temperature reaches its peak at 12:00 until 13:00. The highest air temperature is at point 2 , which is $30^{\circ} \mathrm{C}$ at $12: 06$ until $12: 11$ and highest humidity is at point 3 , which is $91 \%$ at $17: 10$ to $17: 16$, respectively. While Sukajadi 
show the same pattern between one point and another. The highest air temperature is $32^{\circ} \mathrm{C}$ obtained from spot 1 at 11:52 to 11:57. For the relative humidity, the graph tends to be inversely proportional to the air temperature. Humidity in the morning at 06:00 to 10:00 is higher than humidity during the day from 11:.00 to 12:00. The highest humidity is at spot 3, which is $74 \%$ at $16: 48$ to 16:53. For Cigondewah Kidul, the air temperature reaches its peak at 12:00 until 13:00. The highest air temperature is at spot 2 , which is $30^{\circ} \mathrm{C}$ at $12: 06$ until 12:11. The highest humidity is at spot 3 , which is $91 \%$ at $17: 10$ to $17: 16$.

With four round measrements at the Nyengseret, the highest air temperature is at spot 6 , namely $32^{\circ} \mathrm{C}$ at $11: 17$ until $11: 22$. While the humidity in the morning tends to be lower than humidity in the afternoon to late afternoon. The highest humidity is at spot 5 , which is $80.5 \%$ at $06: 18$ to $06: 23$. By changing the round of measurement, where Tamansari are carried out in five rounds. The highest air temperature is at spot 6 , which is $33^{\circ} \mathrm{C}$ at $11: 42$ until 11:51. While the humidity in the morning tends to be lower than the humidity in the afternoon to late afternoon. The highest humidity is in spot 5, which is $81.98 \%$ at $07: 06$ until 07:11.

For Cihaur Geulis, the highest air temperature is similar to Babakan Ciamis at spot 6, which is $32^{\circ} \mathrm{C}$ at $11: 42$ until $11: 51$. While the humidity in the morning tends to be lower than humidity in the afternoon to late afternoon. The highest humidity is in spot 5 , which is 74\% at 17:00. At the Cicendo, the measurement with four rounds observed that the highest air temperature was at spot 1 , which was $35^{\circ} \mathrm{C}$ at 10:49 until 11:00. While the humidity in the morning tends to be lower than humidity in the afternoon to late afternoon. Similar to Cihaur Geulis with five round measurements, Babakan Ciamis showed the highest air temperature is at spot 6 , which is $33^{\circ} \mathrm{C}$ at $11: 42$ until $11: 51$. While the humidity in the morning tends to be lower than humidity in the afternoon to late afternoon. The highest humidity is in spot 5, which is $81.98 \%$ at 07:06 until 07:11. While at the Sukapada, the research was conducted in seven rounds. The air temperature reaches its peak at 13:00 to 14:00. The highest air temperature is at spot 2 , which is $35^{\circ} \mathrm{C}$ at $14: 10$ until $14: 15$. While the humidity in the morning tends to be lower than the humidity in the afternoon until late afternoon. The highest humidity is at spot 4 , which is $78.35 \%$ at 06.49 to $06: 54$.

\subsection{Discussion}

Based on data and information that has been collected on those spots, the interpolation map of temperature could be produced. There are 3 maps that has been analyzed such as morning temperature, mid-day temperature, and afternoon temperature. The interpolation of temperature are limited for 4 sub-city areas such as Bojonegara, Tegalega, Cibeunying, and Karees (see Fig. 1). 


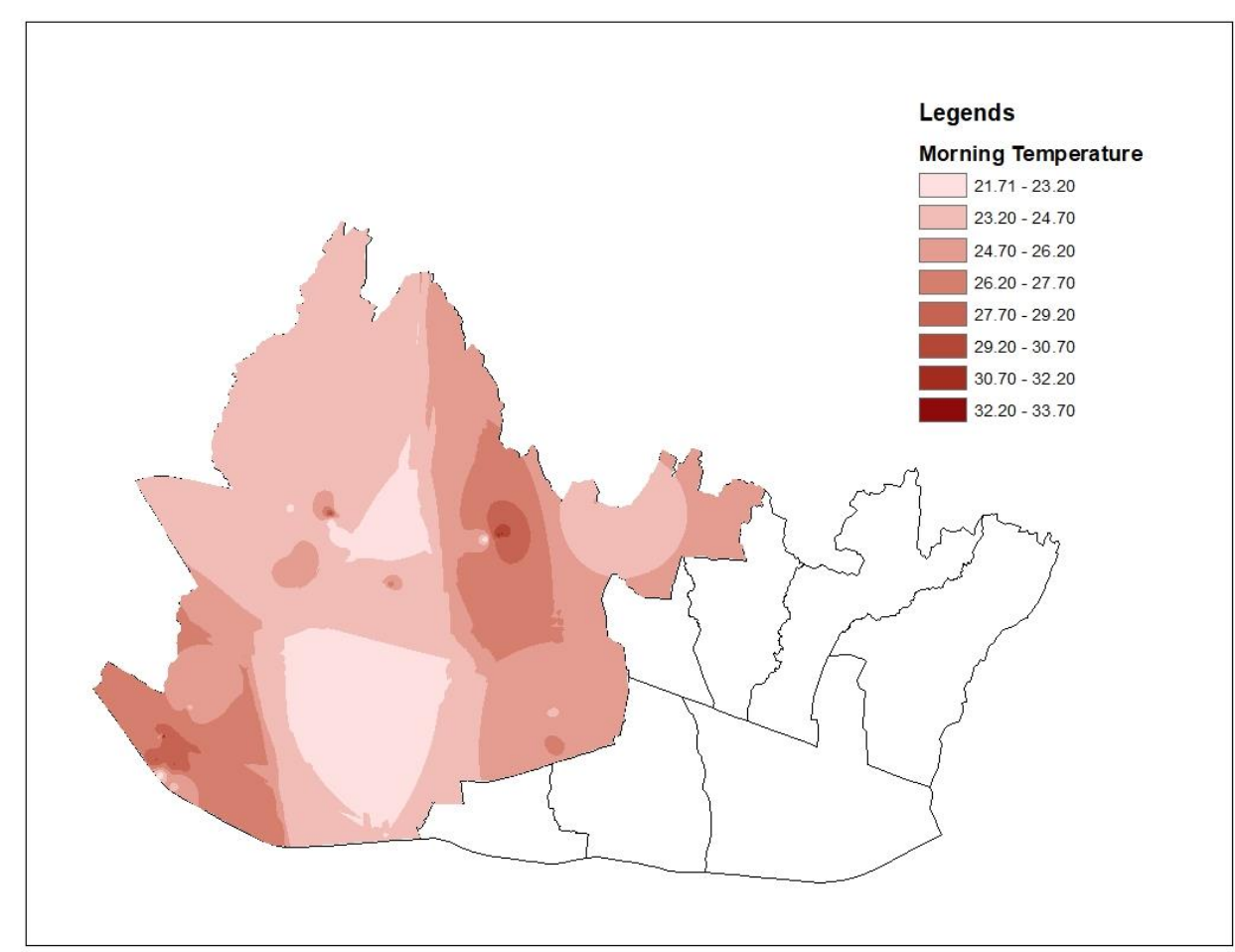

Fig. 1. Morning Interpolation Climate map.

The lowest temperature in the morning is around $21.71^{\circ} \mathrm{C}$ while the highest is $33.70^{\circ} \mathrm{C}$. The higher temperature, based on interpolation map are located in southwest (Cigondewah) and northeast (Sukapada) of Bandung. At midday, the highest temperature is $34.18{ }^{\circ} \mathrm{C}$ and most of them are located in Central of Bandung City (Karees Sub-city area). The lower temperature is $27.63^{\circ} \mathrm{C}$, however in general most of area in Bandung in the day have temperature more than $30^{\circ} \mathrm{C}$. This alteration can be seen at Fig. 2. In the afternoon, the highest temperature is $32.25^{\circ} \mathrm{C}$ with the lowest is $22.40^{\circ} \mathrm{C}$. Fig. 3 shws the locations with temperature higher than $27^{\circ} \mathrm{C}$ are mostly located in Karees and South of Cibeunying subcity areas. 


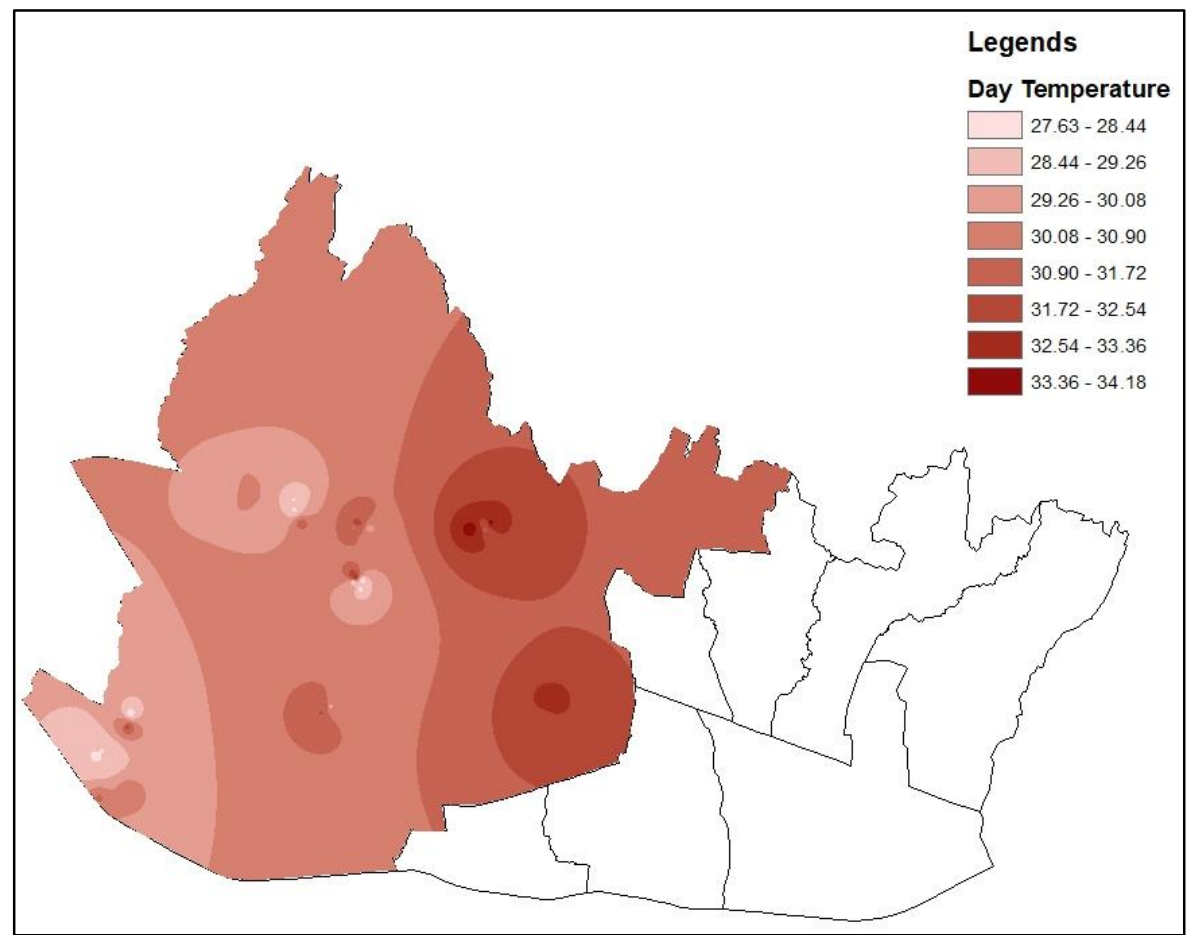

Fig. 2. The urban climate alteration in the mid-day.

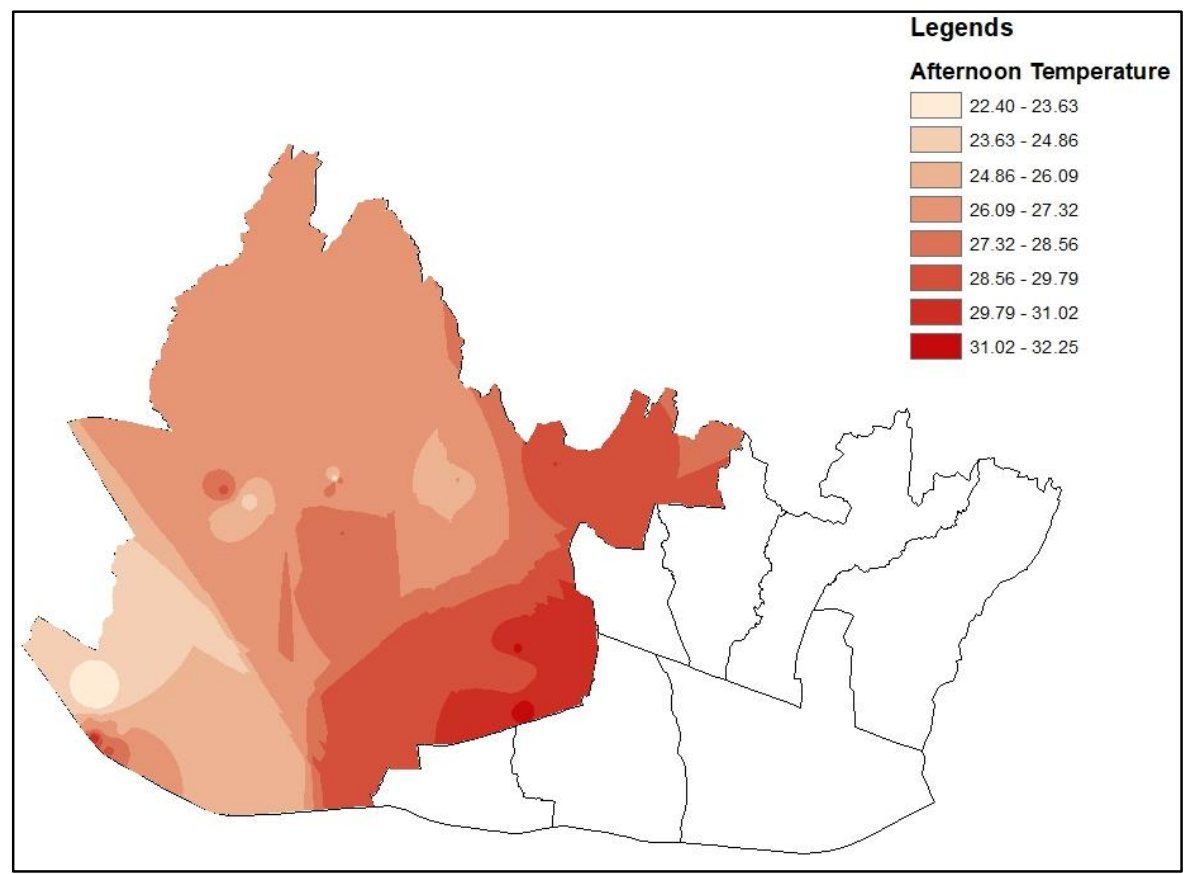

Fig. 3. The urban climate alteration in the afternoon. 


\section{CONCLUSION}

Analysis and measurement of aspects of microclimate have been carried out in this study. In terms of city forms and microclimates, comparative studies from nine experimental sites provide a thoughtful that geographical locations play a significant impact in creating a microclimate. The urban structure defined by the building coverage ratio (BCR), floor area ratio (FAR), and canyon (H/W) not only affects the microclimate but also the location of the building. When compared with previous research in 2013, where the peak of the dry season in Bandung occurred in July-August each year, it was clear that there were significant weather changes. The high value of humidity that occurs in the morning needs to be investigated more deeply, especially in relation to anthropogenic release and evapotranspiration of the Earth's surface.

The results showed by low temperatures in July, where global temperatures almost the same as air temperatures, which resulted in lower average radiation temperatures. This indicates the perception of outdoor thermal comfort tends to be neutral. While solar radiation from global temperatures in previous studies showed average temperature radiation was as a major factor in the increase in microclimate, which also increases the perception of outdoor thermal discomfort. However in this study, high anomalies from humidity appeared the main contributing factor to increase the perception of discomfort level and impact on changes in microclimate.

\section{ACKNOWLEDGEMENTS}

Authors would like to thanks to Fukuda Lab, The University of Kitakyushu for the instrument tool. Building Science Research Team of DPTA-UPI.

\section{R E F E R E N C E S}

BNPB (2014) Data Bencana Kota Bandung” http://data.go.id/dataset/data-bencana-kota-bandung [Accessed March 2019]

BPS Bandung (2016) Bandung City in Figure, Bandung: BPS. https://bandungkota.bps.go.id/subject/151/iklim.html\#subjekViewTab3 [Accessed March 2019]

Demographia (2017) Demographia world urban areas and population projections. Demographia, http://www.demographia.com/db-worldua.pdf [Accessed March 2019]

Gavris, A. (2012) Exploring spatial syntax in bucharest city. Geographia Technica, 2, 23 - 31.

Gunawan, I., Sagala, S., Amin, S., Zawani, H. \& Mangunsong, R. (2015) City risk diagnostic for urban resilience in Indonesia. Jakarta: The World Bank.

Kalnay, E. \& Cai, M. (2003) Impact of urbanization and land-use change on climate. Nature, 423, $528-531$.

Malakoff, D., Wigginton, N. S. Fahrenkamp-Uppenbrink, J. \& Wible, B. (2016) Use our infographics to explore the rise of the urban planet. Sciencemag. http://www.sciencemag.org/news/2016/05/use-our-infographics-explore-rise-urban-planet [Accessed March 2019]

Manik, T. K. \& Syaukat, S. (2015) The impact of urban heat islands: assessing vulnerability in Indonesia. http://pubs.iied.org/10721IIED/ [Accessed March 2019]

Matzarakis, A. \& Mayer, H. (2008) Dependence of urban climate on urban morphology, In 5th Japanese-German Meeting on Urban Climatology, pp. 277-82.

Matzarakis, A., Rutz, F. \& Mayer, H. (2007) Modelling radiation fluxes in simple and complex 
environments-application of the rayman model. Int. $J$ Biometeorol, 51, 12. doi:10.1007/s00484-006-0061-8.

Narulita, S., Zain, A. F. M. \& Prasetyo, L. B. (2016) Geographic information system (GIS) application on urban forest development in bandung city. In Procedia Environmental Sciences, edited by Yudi Setiawan, Lilik Budi Prasetyo, Iskandar Zulkarnaen Siregar, and Hefni Effendi, 279-89.

Nistor, M. M. (2018) Projection of annual crop coefficients in Italy based on climate models and land cover data. Geographia Technica, 13 (2), 97-113.

Oliveira, V. (2016) The elements of urban form. in urban morphology: an introduction to the study of the physical form of cities. Springer International Publishing Switzerland. doi:10.1007/978-3319-32083-0.

Paramita, B. \& Fukuda, H. (2013) Building groups design strategies in hot-humid climate: a dense residential planning in Bandung, Indonesia. In PLEA 29th. Munich, Germany: PLEA.

Paramita, B. \& Fukuda, H. (2014) Public housing in Bandung an assessment and approaches through urban physics. Advanced Materials 935. doi:10.4028/www.scientific.net/AMR.935.273.

Paramita, B, \& Fukuda, H. (2014) Heat intensity of urban built environment in hot humid climate region. American Journal of Environmental Sciences, 10 (3): 210-218.

Paramita, B. (2016) The land-use of bandung, its density, overcrowded area and public facility toward a compact city. IOP Conference Series: Materials Science and Engineering, 128 (012034).

Paramita, B. \& Fukuda, H. (2014) Public housing in Bandung, an assessment and approach through $\begin{array}{llll}\text { urban } & \text { physics. } & \text { Advance } & \end{array}$ doi:10.4028/www.scientific.net/AMR.935.273.

Ramdani, F. \& Setiani, P. (2014) Spatio-temporal analysis of urban temperature in Bandung city, Indonesia. Urban Ecosystem, 17, 473-87.

Tursilowati, L. (2013) Impact of land use and land cover changes on the urban climate and environment, Studied with Satellite Observation, GIS and Weather Research Forecast Model.

Yusuf, A. A. \& Francisco, H. (2009) Climate Change Vulnerability Mapping for Southeast Asia. Singapore: EEPSEA (Economy and Environment Program for Southeast Asia). http://css.escwa.org.lb/sdpd/1338/d2-5b.pdf [Accessed March 2019] 